\title{
Fazlurrahman's Perspective Islamic Education
}

\author{
Imron Rasyadi \\ (Universitas Islam Negeri (UIN) Sultan Thaha Saifuddin, Jl. Arif \\ Rahman Hakim No.111, Simpang IV Sipin, Jambi, Indonesia) \\ imronrasyadi@uinjambi.ac.id
}

\begin{abstract}
Islamic education, which should be able to answer the challenges of the times because it has multidimensional (profane and intrinsic), in reality, is not able to display its self-image firmly. At the same time, Islamic education is needed to ensure the survival and existence of Islamic society. The purpose of this study is to reveal one side of Fazlurrahman's thoughts on Islamic education because Fazlurrahman, one of the Islamic reformers, tries to find solutions so that Islamic education is more advanced and can answer the challenges of the times. This type of research is library research, and the data source is primary and secondary data. The analytical methods used are inductive, deductive and comparative. The research approach used is qualitative. The results of this study indicate that the background of his intellectual experience influences Fazlurrahman's thoughts. He believes that many things must be reconstructed and reformed in the world of Islamic education, including the goals and the education system. The purpose of Islamic education, which has been defensive-oriented to the hereafter, must be changed to be oriented to the world and the future. In addition, Muslims must take knowledge from the modern West. Fazlurrahman's thoughts are still very relevant today.
\end{abstract}

Keywords: Islamic Education, Thoughts of Fazlurrahman.

\section{Introduction}

Talking about Islamic education today cannot be separated. One of the contributions of thought put forward by a Muslim thinker named Fazlurrahman can be categorized as one of the most severe and productive neomodernist thinkers and a Muslim intellectual figure, which has an interesting background (Ikhwan, 2014).

Rahman has a scientific tradition background that contradicts the traditional Indian Pakistani madrasa scholarship and liberal Western scholarship, both influential in shaping his intellectualism. Presumably, that is what is meant by Syafii Maarif, one of the people who had studied with him who reported that (in his teacher, Rahman 
accumulated the knowledge of a scholar and the ability of a wellknown orientalist) (Ma'arif, 1984).

According to Fazlur Rahman, although efforts have been made to reform Islamic education, the world of Islamic learning is still faced with several problems. The goals of Islamic education that exist today are not directed at positive goals (A'la, 2003).

The purpose of Islamic education is only oriented to the afterlife. It tends to be defensive, namely to save Muslims and the pollution and destruction caused by Western ideas that come through various disciplines, especially ideas that threaten traditional Islamic moral standards (Ma'arif, 1984).

Fazlur Rahman presents an analysis of the development of Islamic higher education. He formulated an alternative methodology of Islamic thought as a formula for a way out of all criticism of the history of Islamic thought. The methodological crisis seems to be well recognized by Rahman as the cause of the decline of Islamic thought. It appears that Rahman sees the alternative methodology as the central point of solving the crisis of Islamic intellectualism.

This methodological alternative implies that it is a big project for Muslims to renew Islamic thought (Anwar, 2021). Rahman realized that this significant project, apart from requiring a long time, also required supporting facilities. The supporting facilities referred to by Rahman are none other than the Islamic education system. The education system must first be modernized, namely, keeping Islamic intellectual productivity by raising its academic standards.

Rahman's perspective on education as the primary means of supporting renewal prompted him to plunge into the criticism of the Islamic learning system that grew in decline and at the beginning of (modern) revival (Mas'adi, 1997).

Rahman compiled a general paper that historically describes the Islamic education system in the Middle Ages, its main advantages and disadvantages, and the modernization efforts carried out in the past century.

The concept of Islamic higher education proposed by Fazlur Rahman is an exciting and urgent issue to discuss because the implementation of Islamic higher education is currently experiencing a dichotomy process, namely applying the methods and content of Western education by adding several Islamic religious subjects with Islamic practices and content originating from the classical era that has 
not been fundamentally modernized (Sunaryo, Sendayu, \& Syam, 2021).

The impact of the existing concept of Islamic education, according to Fazlurahman, is that the implementation of Islamic education has not been able to anticipate the development of a changing era and can only maintain and preserve all classical heritage. This is what causes Muslims always to be left behind and have not been able to face the times.

From this explanation, it can be seen that Fazlurrahman has expressed his thoughts on Islamic education. Thus problems arise for the author about what are Fazlurrahman's thoughts on Islamic Education.

\section{Method}

This research is library research, namely reading and citing books related to Fazlurrahman and his thoughts on Islamic education. The approach used in this research is a qualitative approach, which aims to describe and analyse phenomena, events, social activities, attitudes, perceptions, and thoughts of people individually or in groups (Sukmadinata, 2007). In addition, qualitative research produces analytical procedures that do not use statistical methods or other means of quantification (Ikhwan, 2021).

Thus, the method used is qualitative with a library research approach, which focuses more on collecting relevant sources (such as books, journals, and the internet) related to the title, to answer the problems in this thesis, namely Islamic Education Thought according to Fazlurrahman.

The researcher explores the works or writings of Fazlurrahman as well as sources related to the framework of thinking that builds the ideas put forward by Fazlurrahman about Islamic education.

\section{Result and Discussion}

Fazlur Rahman was born on September 21, 1919 AD, in Hazara District, when India was not yet divided into two states. The area is now located in the northwest of Pakistan. And died on July 26, 1988, in Chicago (A'la, 2003).

His father, Shahab al-Din, was a traditional scholar who graduated from Deoband, a formal madrasa that later developed into a 
well-known Religious College in India (Ma'arif, 1984). His family is known as the 'alim, including diligently carrying out religious worship. Daily worship is carried out regularly and on time, such as prayer, fasting, zakat, hajj, etc. This is proof that his family's condition is that he converted to Sunni and still holds fast to tradition (Amiruddin, 2000).

His father had succeeded in educating his son in the family sphere. For him, education in the family effectively shapes the character and personality of children when facing real life. One of the proofs is that at the age of ten, Rahman has memorized 30 juz of the Qur'an (A'la, 2003).

Although the family's tendency is still to dwell on the form of traditional society, the pattern of family behaviour is very accommodating to the elements of modernity. His father highly valued the modern system of education. Perhaps it was his family's encouragement that influenced Fazlur Rahman's thoughts in the future.

According to Fazlur Rahman, several factors have shaped his character and depth in religion. One of them is teaching from his mother about honesty, compassion, and wholehearted love. Another thing is that his father is diligent in teaching religion to Fazlur Rahman at home with high discipline to face various civilizations and challenges in the modern world (Amiruddin, 2000).

In 1940, Fazlur Rahman completed his academic education with a Bachelor of Art (BA) in Arabic at Punjab University Lahore. In 1942 he obtained a Master's degree (MA) at the same University (Amiruddin, 2000). Gelar akademik yang dimiliki Rahman ini dianggapnya kurang memberikan kepuasan dalam nalar intelektual. Sebab ia menilai bahwa gelar akademik di Pakistan hanyalah formalitas-akademik.

Not much different from local studies, which for him lack a lot of critical insight about Islam. To achieve his goals in Islamic studies, he did not continue to study in the Middle East. But he tried to break through the Western world. At 27 years (1946), Fazlur Rahman left for doctoral studies at Oxford University, England (Tim Penulis IAIN Syarif Hidayatullah, 1992).

His dissertation was on Ibn Sina under the guidance of Professor S. Van den Bergh and H.A.R. Gibbs. He earned a PhD (Philosophy Doctor) degree in 1949. Previously, Fazlur Rahman had also completed his $\mathrm{PhD}$ in Lahore, India (A'la, 2003). It is suspected that, 
in Fazlur Rahman's view, the quality of Islamic higher education in India was deficient, so he was not satisfied with the degree he received in Lahore, India.

On July 26, 1988, Fazlurrahman, professor of Islamic thought at the University of Chicago, died at the age of 69 after being hospitalized in Chicago for a long time due to diabetes and heart disease going on a long time (A'la, 2003).

\section{Fazlurrahman's Thoughts About Islamic Education}

Fazlurrahman's thoughts on Islamic education are motivated by the atmosphere of the revival of knowledge with various problems after the reform movement in the Middle East. The renewal movement was indeed based on the shock of western progress as well as the awareness that arose among Muslims towards science, but it also generated a humanist spirit that was quite useful for later thinkers, Fazlurrahman himself stated "that the renewal of classical modernism has at least attempted to carry out internal reforms, namely instilling rationalism as an initial solution to congestion and intellectual decline." That's why humanistic religious values are so thick in fazlurrahman's thinking, including when discussing religion and knowledge. This issue is important in order to lay the foundations of Islamic education, because how to educate if educators do not understand in advance what they want to teach students.

\section{Relationship between Religion and Science}

Previously, it was also mentioned that Fazlur Rahman tried to address the issue of how to connect religion with knowledge, which became the most crucial discussion in his time, even today. If Seyyed Hossein Nasr and Syed Muhammad Naquib al-Attas speak only at axiology, then Fazlur Rahman tries to initiate it at the level of ontology and epistemology.

Initially, Rahman criticized the views of his predecessors, who thought that there was something wrong with science. He stated that there is nothing wrong with science. Only those who use it can bring science to things that harm Muslims. Good and bad depending on the wearer. He likens science to a knife in a human hand (Rahman, 2005).

Here Rahman has laid the ontological foundation of knowledge, namely that knowledge is an entity outside and within religion. Out means knowledge is free from all forms of egoism and religious identity and is universal, while inside means knowledge comes from God. 
This is by what is explained in the Qur'an, namely that all knowledge comes from Allah. Some of it is revealed to His chosen people through the verses of the Qur'an and partly through the poems of the Kauniyyah, which are obtained from the Qur'an. Humans by using their senses and reason (Rahman, 2005). Thus, the revealed knowledge has absolute truth, while the knowledge obtained by the senses and reason is not whole truth.

Rahman also stated that in the Qur'an, the word "al-'ilm" (science) refers to all kinds of knowledge. For example, when Allah taught how David made armour, it was also al'-ilm. Even magic (sihr), as Harut and Marut taught humans, is also a type of al'-ilm, although it is terrible in terms of practice and use because many abuse magic to separate husbands from their wives. Likewise, things that give new insights to the mind, including al'ilm (Sibawaihi, 2004).

From the description above, it can be understood that Allah's knowledge can be known and studied through two paths, namely the path of the Quran and the Kauniyyah verses. Both explain each other, but the explanation is obtained by human interpretation. Humans in Rahman's thought, once again, have a high place in the authority of science, so we can conclude that science must be integrated.

Thus, there is no dichotomy, or the simple language of terminology, between the so-called general sciences and the religious sciences. Everything is integrated in a multidisciplinary manner. For example, when we study fiqh, we also study sociology, history, administrative science, and others. When we look at theology or kalam, we also research anthropology, astronomy, and others.

It is natural that Rahman's thoughts later appeared in various forms of thought modification, such as the interpretation of the Koran based on the socio-cultural context or the hermeneutics of the Koran and Islamic liberalism, the performance of the Koran based on the spirit of liberation as in Ashghar Ali's work. Engineer, the interpretation of the Qur'an is based on the views of a civil engineer such as Muhammad Shahrur and others. This view of the integration of science shows that Fazlur Rahman planted the foundation of epistemology.

According to Fazlur Rahman, education has long been known in the Islamic intellectual tradition, namely since the beginning of Islam. In the early days, education was synonymous with Islamic da'wah efforts. Therefore education developed in line with the development of religion itself. 
Fazlur Rahman stated that the arrival of Islam brought for the first time a specific educational instrument with religious culture, namely the Qur'an and the teachings of the Prophet. However, it should be understood that in the early days of the development of Islam, of course, systematic formal education was not implemented. The education that takes place can be said to be informal. Even this is more related to the efforts of da'wah Islamiyah-spreading, planting the basics of belief, and worshipping Islam (Sutrisno, 2006).

According to Fazlur Rahman, Islamic education is not just physical equipment and equipment or quasi-physical teachings such as books that are taught or the external structure of education. Still, as Islamic intellectualism, this is what is meant by the essence of Islamic higher education. (Sutrisno, 2006). This is the growth of an original and adequate Islamic thought, which should provide the criteria for judging the success or failure of Islamic education.

Islamic education can include two broad meanings: First, Islamic education in a practical sense, namely education carried out in the Islamic world as implemented in Pakistan, Egypt, Sudan, Saudi, Iran, Turkey, Morocco, and so on, ranging from primary education to university. The Indonesian context includes education in Islamic boarding schools, madrasas (starting from ibtidaiyah to aliyah). Islamic universities can even be Islamic religious education in schools (from elementary to advanced) and public universities. Second, Islamic higher education is called Islamic intellectualism (Rahman, 2005).

More than that, according to Fazlur Rahman, Islamic education can also be understood as a process to produce integrative, dynamic, innovative, progressive, fair, honest people (scientists), and so on. Such scientists are expected to provide alternative solutions to the problems faced by humanity.

\section{Islamic Education Goals}

According to Fazlur Rahman, the purpose of education is to develop human potential so that the knowledge gained will become a creative person, utilize natural resources for the good of humanity, and create justice, progress, and the world order (Rahman, 2005).

Islamic education began in the Middle Ages, carried out mechanically. Therefore, Islamic education is more inclined to the cognitive aspects of the practical and psychomotor aspects. The current strategy of Islamic education, according to Rahman, is defensive, namely to save Muslims from pollution or damage caused by the impact of Western ideas that come through various disciplines, 
especially ideas that will threaten to destroy standards. Islamic traditional morality (Amal, 1993). According to Fazlurrahman, Muslims face multiple problems, including:

1. Muslims have an ideological problem. They do not link the importance of knowledge with its ideological orientation effectively. As a result, the Muslim community is not encouraged to learn. They have no purpose in life. In general, to the failure to link the educational achievements of Muslims with their ideological mandate. People are not aware that they are under the moral imperative of Islam to seek knowledge.

2. Regarding the second problem explained. Closely related to the first is the great disaster of Muslims with dualism, a dichotomy in the education system. On the one hand, the so-called "ulama" education system is implemented in madrasas. So lagging that now the results are truly disappointing. The product of this system, according to Rahman, cannot live in the modern world and cannot keep up with the times. The curriculum and its syllabus must be radically and fundamentally changed to compete in contemporary life. The basic principles of social science, a world view of modern science and an introduction to world history and modern humanities should be included in the syllabus to add to the specialized religious disciplines. However, it is also essential to understand that the current education system of Islamic society implemented in universities has entirely developed without touching the ideology and social and cultural values of Islam. Students are not inspired at all by noble ideals. The tragic result is that our educational standards are deteriorating and below.

3. Regarding the third problem, Rahman explained that related to that, and there is another equally important problem, namely the language problem. Language problems are always related to higher education and thinking. We are likened to a Muslim society without language. Pure concepts never arise in the mind unless it is born with words (language). Quality concepts will not emerge if there are no words (because there is no adequate language). As a result, imitation and repetition like that of a parrot is not an original thought. The language contradictions that are often raised should be separated from political emotionalism. Muslims now have to develop one language adequately and quickly because they are in a race against time. The world's progress will not stop 
waiting for them, and there is no particular reason to humiliate them behind.

Rahman further gave a particular example in Pakistan, and namely, if Muslims in Pakistan still aim as one nation, they are required to have one language. Once they have a single language decision, they must develop it well and without wasting time.

Then, they oblige themselves to think, write, and read in that language. Rahman admits that, during this time, he has thoughts that are valuable in writing in English. However, as a nationalist, he still considers English a foreign language until now (Sutrisno, 2006). however, they also have not developed both Urdu and Bengali, which should sincerely and urgently deserve to be developed.

Both languages have a history and literature and certainly have the potential to develop, i.e. Urdu has the advantage of being closely related to their traditions, but the issue of language has unfortunately become the subject of emotional, political debate. Their minds are certainly not reasonable when they argue, even though they should be qualified and creative thinkers.

Imitating terms and phrases like a parrot is still the basis of Islamic education methodology as a logical consequence of not having a language capable of expressing a solid thought process. Unfortunately, some of them come from the legacy of the madrasa education system. Over the past few centuries, madrasa education has concentrated on books rather than subjects (Rahman, 2005).

Children are taught to learn by memorizing, not to process their minds creatively. As a result, the growth of concepts will be damaged. Knowledge is not something creative, but obtained, both in books and in the minds of teachers, has been acquired and stored for a long time. This is what is called "science".

This concept is opposed to the view of knowledge as something of continuous growth advocated by the Qur'an. The tragedy also occurs in modern Islamic educational institutions. Learning by memorizing on a large scale is practised, and textbooks and the implementation of exams are continuously worrying.

From the description above, Rahman gives an overview of education in the Muslim community in the medieval and pre-modern eras: the main weakness felt in the learning process in the Muslim community in the Middle Ages and the pre-modern period was their conception of knowledge. Knowledge). Contrary to the attitude and 
way of thinking of modern science, they view knowledge as something that basically must be sought and found or built systematically by the human mind itself.

By relying on the role of the human mind to acquire knowledge, medieval scientific attitudes emphasized that knowledge is "acquired". The philosophy and position of the reason are more passive and receptive than creative and upbeat.

From the explanation above, it can be understood that when talking about education, Fazlur Rahman first criticized the development of educational thought in his time, namely the nuances of Islamic modernism brought by the reformers. According to him, the goals of Islamic education that existed were not directed at positive goals.

The purpose of Islamic education only tends to the afterlife. It tends to be defensive, namely to save Muslims from the pollution and destruction caused by the impact of Western ideas that come through various disciplines, especially ideas that threaten traditional Islamic moral standards (Rahman, 2005).

In this condition of spiritual panic, the Islamic education strategy developed throughout the Islamic world is mechanical. As a result, some groups reject everything that smells of the West. Some even forbid the takeover of science and technology so that if this condition continues, it will lead to the decline of Muslims.

According to Rahman, several things must be done:

1. The goal of Islamic education, which is defensive and tends to be oriented only to the afterlife, must be changed immediately. The purpose of Islamic education must be introduced to the life of the world and the hereafter and sourced from the Qur'an.

2. The psychological burden of Muslims in facing the West must be removed immediately. For this, Rahman recommends that a comprehensive historical (contextual) and systematic (logical) study of Islam be carried out on the development of Islamic scientific disciplines, such as theology, law, ethics, hadith, social sciences, and philosophy. by adhering to the Qur'an as the basis of values. The discipline of Islamic sciences that has developed in history makes the intellectual and spiritual life of the Muslim community run dynamically. Through these efforts, it is hoped that the psychological freedom of Muslims in facing the West can be lost. 
3. The negative attitude of Muslims towards science must also be changed. According to Rahman, there is nothing wrong with science, and it is the users can go wrong.

The problem of the dualism dichotomy of the education system has hit all Muslim countries or countries where the majority of the population is Muslim. Even according to Syed Sajjad Husain and Syed Ali Ashraf, "the dichotomy of the education system is not only about differences in its external structure but also differences that arise from their approach to educational goals" (Nata, 2013).

The ancient traditional system in Islam is based on a set of values derived from the Qur'an. In the Qur'an, it is stated that the fundamental aims of education are to create human beings who are obedient to God and will always try to obey His commands as written in the holy book.

Such a person will try to understand all phenomena inside and outside the treasures of God's power. On the other hand, the modern system, which does not explicitly exclude God, tries not to involve Him in its explanation of the universe's origin or the phenomena with which humans are in daily contact.

Amid the rampant problem of the dichotomy of the Islamic education system, Fazlur Rahman tries to offer a solution. According to him, "To eliminate the paradox of the Islamic education system is to integrate the religious sciences with the general sciences organically and comprehensively. Because basically, science is integrated and cannot be separated (Muhaimin, 1999).

Thus, the curriculum and syllabus of Islamic education must include general sciences such as social sciences, natural sciences and world history, and religious sciences such as fiqh, kalam, interpretation, and Hadith.

According to the author, the integration method as offered by Rahman was once applied in the golden age of Islam. At that time, science was studied in its entirety and in the balance between the sciences needed to achieve prosperity in the world (general sciences) and the sciences to achieve happiness in the hereafter (religious sciences). There was no dichotomy between the public and available sciences. Spiritual knowledge can lead Muslims to achieve satisfaction in this world and happiness in the hereafter.

\section{Educational Renewal According to Fazlurrahman}


The term modern means the period from 1800 AD onwards (Nasution, 1994). The modern world is marked by the rapid development of science and philosophy in Europe after a long reign in the Islamic world. This situation further shows the decline of the Islamic world compared to the Western world.

The decline in the Islamic world occurs because of the wrong view of Muslims towards the current education system. Among the criticisms made by Fazlur Rahman that the purpose of Islamic education is now only oriented to the afterlife and is defensive, and there is a dichotomy or separation between general knowledge and religious knowledge.

In the historical study of the dichotomy of science, Islam is in stark contrast to the West, which wants a scientific paradox. For the Islamic world, that dichotomy is very dangerous. The dichotomy view can threaten the realization of Islam in people's lives. If the contradiction develops in the Islamic world, one of the consequences is a division between general science and religion.

Circumstances like this prompted Fazlur Rahman to spark ideas for change so that Muslims could compete with other nations in education. With a passionate spirit, they contribute to Islam and the world, both in energy, criticism, scientific works, etc. One of the reform efforts made by Fazlur Rahman in the education system is to integrate knowledge.

The concept of integrating science needs to be done to avoid discrimination in knowledge. As stated by Muhaimin, to understand the concept of scientific integration, the first step that must be done is to understand the context of the emergence of the idea of scientific integration. "The origin of the emergence of the idea of integrating science is the existence of a view or attitude to distinguish general science (science) and religious science (religious)" (Muhaimin, 1999).

According to Fazlur Rahman, the purpose of integration is so that Islamic education does not seem obsolete by the times. It should also be understood that the idea of scientific integration is intended as an effort to build a positive attitude towards religious and general sciences.

The keyword concept of scientific integration departs from the premise that all proper knowledge comes from God. This gives an understanding that there is no need for a dichotomy in science. So the integration of science is present as a solution to the problem of the scientific contradiction that occurs. 
Based on this description, it can be understood that the idea of renewal promoted by Fazlur Rahman is essential for the development of Islamic science in the future to compete in the modern world. Fazlur Rahman's ideas about the concept of integration of science and others are doors that can lead Muslims to achieve their glory again after being captured by the Western world for a long time.

Fazlur Rahman's thoughts have been responded to by many Islamic countries, including Indonesia, to develop education. The concept of education integration has been applied to start from primary, secondary and tertiary education. Such as the existence of an Integrated Islamic education system, such as Agus Shofwan's statement as quoted by Zubaedi, "that integrated Islamic education is a form of education unit that organizes educational programs based on the National Curriculum enriched with the Islamic education system through integration between religious and general education" (Zubaedi, 2012).

From the explanation above, it can be understood that several Islamic universities in Indonesia have tried to erase the dichotomy between religious and general sciences. However, according to Fazlur Rahman, the world of Islamic education in Islamic countries has not eradicated the contradiction between the religious sciences and the sciences. In general, the result is the low intellectual quality of students and the emergence of split personalities from Muslims. For example, a Muslim who is pious and obedient to worship, at the same time he can become an extortionist, oppressor, corruptor, or commit other disgraceful acts (Sibawaihi, 2004).

It is even more ironic that the dichotomy of the education system has resulted in the absence of students who have a deep spiritual and intellectual commitment to Islam from Islamic educational institutions. Some of them are more involved as technical players in religious matters. While the spirit of religion itself is rarely really intensely and intimately wrestled with.

According to Rahman, several efforts must be made to overcome the problems mentioned above, among others:

1. Students must be taught Al-Qur'an lessons through methods that allow the holy book to be used as a source of moral inspiration and to be used as the highest reference for solving problems in everyday life that are increasingly complex and challenging. The first movement has two steps: a. One must understand the meaning or significance of a statement by examining the historical 
situation and problems of the Qur'an. b. Generating those specific answers and stating them as statements with a general moral and social purpose that can be filtered from particular verses in the light of frequently stated socio-historical backgrounds.

2. Provide material in the disciplines of Islamic sciences historically, critically and holistically. The fields of the Islamic sciences include Theology, moral law, social sciences and philosophy.

To get such quality educators in Islamic educational institutions today is very difficult. This is evidenced by Rahman's observations of the development of Islamic education in several Islamic countries. He saw that qualified and professional educators have creative and integrated minds who can interpret old things in a new language as far as substance is concerned and make new things valuable tools for ideals that are still challenging to find in this era modern.

\section{Conclusion}

From the explanation above, several conclusions can be drawn. According to Fazlur Rahman, many things still need reconstruction and renewal in the Islamic world because education plays a vital role in forming generations of Muslims who have intellectuality. And able to provide new directions for Muslims to return to the golden world of Islam in the past. Contributions to efforts to modernize Islamic education are several aspects, including the goals of Islamic education and the Islamic education system. Furthermore, the renewal of education, according to Fazlurrahman, is by removing the dichotomy of schooling. The trick is to teach al-Qur'an lessons to students through possible methods so that students understand the meaning and intent of the verses of the Qur'an because the holy book is not only used as a source of moral inspiration but can also be used as the highest reference for solve problems in everyday life that are increasingly complex and challenging. In addition, a teacher must provide material in the disciplines of Islamic sciences historically, critically and holistically. The fields of the Islamic sciences include Theology, moral law, social sciences and philosophy. 


\section{Bibliography}

A'la, A. (2003). Dari Neomodernisme ke Islam Liberal: Jejak Fazlur Rahman dalam Wacana Islam di Indonesia. Jakarta: Paramadina.

Amal, T. A. (1993). Islam dan Tantangan Modernitas: Studi Atas pemikiran Hukum Fazlur Rahman. Bandung: Mizan.

Amiruddin, M. H. (2000). Konsep Negara Islam Menurut Fazlur Rahman. Yogyakarta: UII Press.

Anwar, S. (2021). Internalisasi Nilai Pendidikan Akhlak dalam Surat Al-Hujurat Tafsir fi ZIlalil Qur'an. JIE: Journal of Islamic Edication, 6(1), $1-12$.

Ikhwan, A. (2014). Integrasi Pendidikan Islam (Nilai-Nilai Islami dalam Pembelajaran). Ta'allum: Jurnal Pendidikan Islam, 2(2), 179194.

Ikhwan, A. (2021). Metode Penelitian Dasar (Mengenal Model Penelitian dan Sistematikanya). Tulungagung: STAI Muhammadiyah Tulungagung.

Ma'arif, A. S. (1984). Fazlur Rahman: al-Qur'an dan Pemikirannya dalam Islam, Edisi Indonesia. Bandung: Pustaka.

Mas'adi, G. A. (1997). Pemikiran Fazlur Rahman tentang Metodologi Pembaharuan Hukum Islam. Jakarta: Raja Grafindo Persada.

Muhaimin. (1999). Kontroversi Pemikiran Fazlur Rahman Studi Kritis Pembaharuan Pendidikan Islam. Cirebon: Pustaka Dinamika.

Nasution, H. (1994). Pembaharuan dalam Islam: Sejarah Pemikiran dan Gerakan. Jakarta: Bulan Bintang.

Nata, A. (2013). Pemikiran Pendidikan Islam dan Barat. Jakarta: Raja Grafindo Persada.

Rahman, F. (2005). Islam dan Modernitas tentang Transformasi Intelektual terj.Ahsin Mohammad. Bandung: Pustaka.

Sibawaihi. (2004). Eskatologi al-Ghazali dan Fazlur Rahman: Studi Komparatif Epistemologi Klasik-Kontemporer. Yogyakarta: Islamika.

Sukmadinata, N. S. (2007). Metode Penelitian Pendidikan. Bandung: PT Remaja Rosdakarya.

Sunaryo, S. A., Sendayu, F. S., \& Syam, A. R. (2021). Internalization of Huma Betang Cultural Values through Narrative Counseling for Elementary Education Students. JURNAL INDRIA (Jurnal 
Ilmiah Pendidikan Prasekolah Dan Sekolah Awal), 6(1).

Sutrisno. (2006). Fazlur Rahman; Kajian terhadap Metode, Epistemologi dan Sistem Pendidikan. Yogyakarta: Pustaka Pelajar.

Tim Penulis IAIN Syarif Hidayatullah. (1992). Ensiklopedi Islam Indonesia. Jakarta: Jembatan.

Zubaedi. (2012). Isu-isu dalam Diskursus Filsafat Pendidikan Islam dan Kapita Selekta Pendidikan Islam. Yogyakarta: Pustaka Pelajar. 